\title{
ENVIRONMENTAL CONDITION OF KECSKEMÉT FROM THE POINT OF VIEW OF THE CLIMATE CHANGE
}

\author{
Edit Hoyk* \\ Department of Agroeconomy and Rural Development, Faculty of Horticulture and Rural Development, John \\ von Neumann University, Hungary \\ Great Plain Research Department, Institute for Regional Studies, Centre for Economic and Regional Studies, \\ Hungary \\ https://doi.org/10.47833/2020.2.AGR.023
}

\author{
Keywords: \\ climate change \\ adaptation \\ environmental condition \\ air quality \\ green infrastructure
}

Article history:

Received

Revised

Accepted

\begin{abstract}
Nowadays climate change has become a reality. As a result, the focus has been on avoiding, mitigating and adjusting to expected adverse effects.

In this study, we focus on Kecskemét, which is the largest city on the sand ridge between the Danube and Tisza rivers. The city is highly exposed to the negative effects of the climate change, that is why we investigated the elements of the environmental condition in the city. These elements have a significant role on the adaptation.
\end{abstract}

\section{Introduction}

Reducing $\mathrm{CO}_{2}$ emissions to the atmosphere (eg. through energy saving, increasing energy efficiency, using new management solutions and technologies, significant societal change and raising environmental awareness) is the most important area in the fight against climate change. The task is to remove $\mathrm{CO}_{2}$ from the atmosphere with plants and afforestation, but there are also experimental industrial processes for $\mathrm{CO}_{2}$ syngas conversion.

This is particularly important as global atmospheric $\mathrm{CO}_{2}$ concentrations reached a peak of 415 ppm in May 2019 (NOAA 2019). Given the rise in the last decade, $\mathrm{CO}_{2}$ levels could reach the second half of the 2030s $450 \mathrm{ppm}$, which is linked to a $+2 \mathrm{C}^{\circ}$ change in global average temperature rise as a critical value [4].

\section{Carbon footprint of Kecskemét}

For 2014, based on the average annual emissions of the population based on the data of KSH (Central Statistic Office of Hungary), Kecskemét „emits” 640820 t CO 2 (5.73 t/capita/year). Adjusted for this value with annual data on electricity and gas consumption, today $\mathrm{CO}_{2}$ emission is $770229 \mathrm{t}$ per year (6.88 t/capita/year) [3]. On the capture side, taking into account all vegetation, the model used to build the MOD17A3 v55 database showed a total of $156685 \mathrm{t}$ of carbon sequestered in the city ( $1.4 \mathrm{t} /$ capita/year), taking into account the city-level balance of $613544 \mathrm{t}$. If only forest areas are taken into account (this is more accurate, because, for example, in the case of agricultural crops, carbon is only temporarily stored in plants and soil), the annual absorption value is only $33440 \mathrm{t}$ ( $10 \%$ of the total forest area in Corine Land Cover 2018 data), so the amount of $\mathrm{CO}_{2}$ released into the atmosphere in Kecskemét can exceed 700000 t per year.

On this basis, it can be concluded that the city's carbon footprint is significant. Even in the best case scenario, $\mathrm{CO}_{2}$ emissions are almost twenty times higher than the amount bound by vegetation. While this value is based on a one-year estimate for the carbon balance, other trends related to the state of the environment (eg. increase in the number and circulation of motor vehicles, increase in electricity and gas consumption, decrease in green spaces) suggests that since 2014 further deteriorated. This underlines both the importance and the need for a commitment by the city leadership in the Covenant program and demonstrates that several programs have been proposed over the last few decades (eg. improving air quality, developing sustainable urban mobility, increasing afforestation, improvement of plant quality, modernization of building energy systems, 
development of district heating system, increase of renewable energy production) cannot be postponed.

\section{Air quality in Kecskemét}

An important indicator of the state of the environment is the development of air quality. According to the traffic counting data [6], Between 2014 and 2018 a 12.4\% increase in traffic was recorded within the administrative area of Kecskemét. Stopping this kind of traffic growth is vital for Kecskemét, as $\mathrm{CO}_{2}$ and other air pollutant emissions from road traffic, as well as residential heating - in non-environmentally friendly ways - have become more common, and various air pollutants may become denser in the near future (PM10; $\mathrm{PM} 2.5 ; \mathrm{NO}_{2} ; \mathrm{NO} ; \mathrm{SO}_{2} ; \mathrm{O}_{3}$ ).

From the available data (2009-2019), the concentration of highly transport-dependent nitrogen dioxide $\left(\mathrm{NO}_{2}\right)$ is illustrated in Figure 1. It shows data for the start year, an intermediate year, and the last three years between 2009 and 2019.

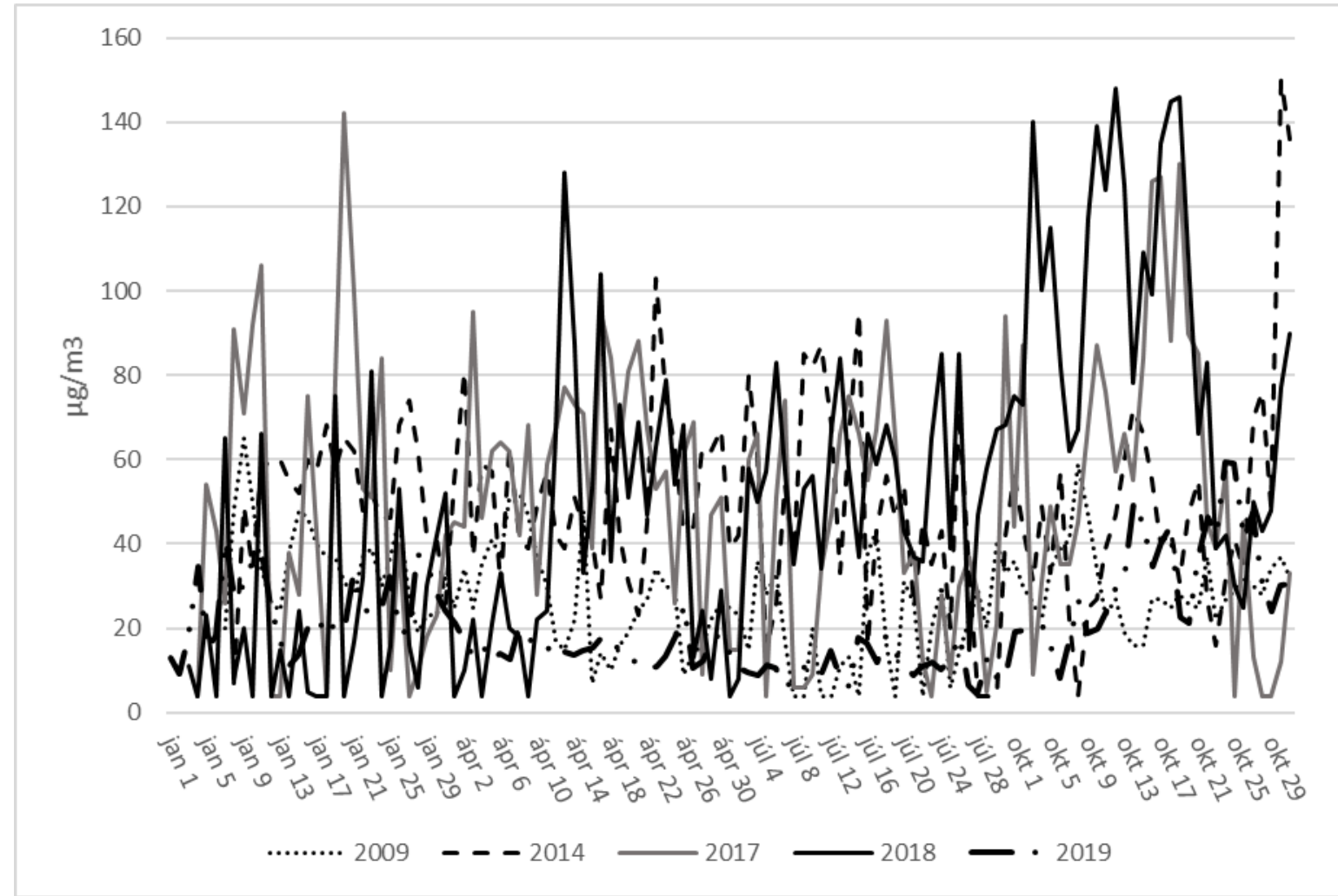

Source: www.levegominoseg.hu

Figure 1. Concentration of $\mathrm{NO}_{2}$ in Kecskemét (2009-2019)

The health limit value for $\mathrm{NO}_{2}$ is $85 \mu \mathrm{g} / \mathrm{m}^{3} /$ day [8]. Figure 1 . shows that over the years (20172018), limit values have been exceeded, mainly in the summer and autumn periods. Nitrogen dioxide as a pollutant is not only related to transport, but also eg. for residential heating, however, summer and autumn limit values are more likely to indicate the origin of traffic. It is worth comparing the percentage increases in monthly averages for 2009 and 2018. The January values are ignored in this case, as there was no overshoot in this month except for 2017. However, in the spring period (April), the average $\mathrm{NO}_{2}$ concentration increased by $57 \%$ in ten years. In July, the two-year growth rate was $169 \%$, compared with $197 \%$ in October. In addition to the steep increase in concentration, the monthly (!) average in October 2018 was $89,67 \mu \mathrm{g} / \mathrm{m}^{3}$, which also an unfavorable process, exceeding the 24-hour limit.

Concentrations of other transport-related pollutant emissions (eg. $\mathrm{CO}, \mathrm{CO}_{2}, \mathrm{NO}, \mathrm{PM} 10$ ) are only available from 2015 and most data series are rather incomplete. The exception is the concentration of PM10 (airborne solid and liquid particulates, also called „suspended dust"). It can 
be said that the data series available from 2015 also shows increasing concentrations, with several limit values $\left(50 \mu \mathrm{g} / \mathrm{m}^{3}\right)$ overshoot, particularly in January 2016 and 2017, October 2018, January 2019 and 2020 (Fig. 2).

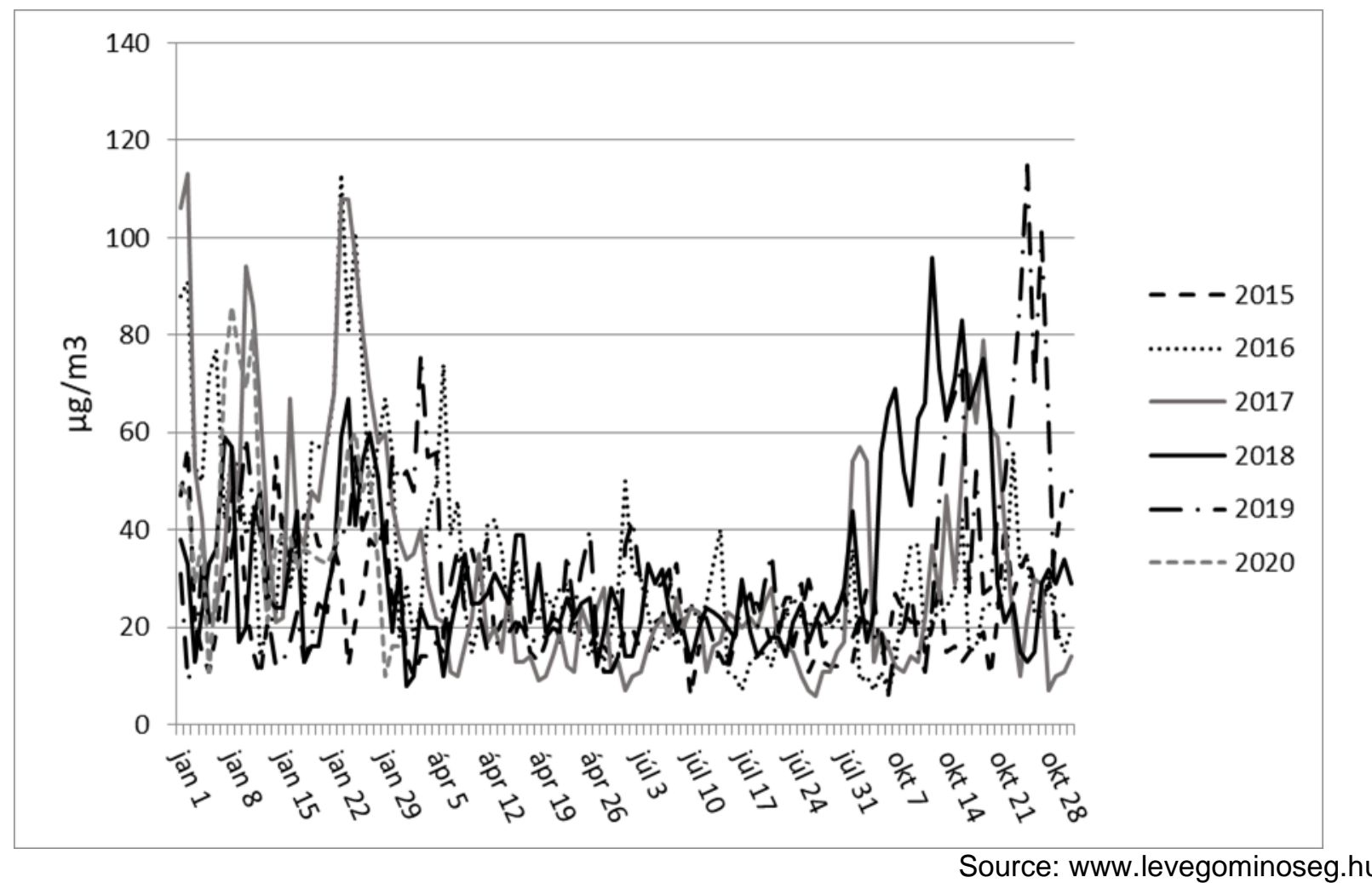

Figure 2. Concentration of PM10 in Kecskemét (2015-2020)

\section{Characteristics of the environmental elements in the city}

The sand ridge between Danube-Tisza rivers and Kecskemét are among the most environmentally sensitive areas of Hungary. The state of the natural elements (soil, air quality, vegetation, hydrological conditions) is part of the environmental sensitivity. As with the evolution of air quality, it is worth briefly reviewing the soil, vegetation and hydrological conditions of the city and its surroundings.

From the point of view of the soils, Kecskemét lies at the junction of the Kiskunság sand ridge and the Kiskunság loess back. Sandy soils have loose structure, good water permeability and poor water retention, which, combined with low rainfall, results in rapid drought, a tendency to drought and wind erosion damage. Loess areas, especially to the south of the settlement, mean more fertile soils that can be used more effectively for agricultural purposes. The aridification of the sand ridge has been traced to the sinking groundwater for decades. Over the last 40 years, the mean value of the groundwater level sinking between Danube and Tisza rivers was 1,5-2 meters, which in some cases reached 6-7 meters [2; 5; 7]. The loss of groundwater highlights the crucial importance of water conservation and irrigation problems, which not only adversely affect agriculture, but also make it difficult to manage urban green areas and maintain green infrastructure. That is why it is important to emphasize the solutions and opportunities that focus on water retention and rainwater storage.

Land cover and vegetation are closely interrelated factors that determine the degree of close to nature state of the landscapes on the one hand, and the establishment of a liveable environment in a settlement environment on the other. In addition, they influence land use and changes in land cover. In case the land use does not meet the conditions provided by the natural environment (eg. agricultural production is not adapted to the soil and/or climatic conditions), we are talking about land use anomaly [1]. Over the past decade, the number of land use anomalies in the Kecskemét region 
has increased. One of the manifestation of this is the decrease of green areas - the expansion of city council owned green areas within the administrative border of Kecskemét decreased by 30,7\% between 2008-2018, based on KSH data - which is mainly due to the expansion of the southern industrial area. Another disadvantage of the growth of built-up areas is that the industrial facilities are located in the areas that represent the most fertile areas of the city, which can be interpreted as a very significant anomaly of landscape use.

In addition to protecting green areas, we should be optimize land use/land cover in the interest of create a so-called compact city, where the optimal use of different city functions - by analyzing daily spatial paths - would reduce the city's energy and resource use.

\section{Urban green infrastructure}

Intra-urban soil conditions, combined with air pollution mean a challenge the expansion and maintenance of green infrastructure. Urban soils with poor water management, degraded structure and poor nutrient supply can only be successfully planted with broad tolerance, possibly non-native woody vegetation. In areas where woody plants are not feasible, the selection of mulch vegetation may be important, highlighting the importance of careful green space maintenance and variety selection. However, the development of green infrastructure would also require the complex application of city-level water management solutions. These include, in particular, the expansion of underground rainwater storage options and solutions for surface desiccation. These include the reduction of paved surfaces, the development of water-permeable pavements, the replacement of existing pavements with water-permeable pavements and designing rain gardens. Rain gardens appeared in the United States in the 1990s and have spread throughout the world over the past 30 years. Artificially formed and planted with vegetation, a deeper surface in the soil for the purpose of storing, temporarily storing and filtering rainwater. Do not mix the so-called bio ditches, the rain garden is a flat surface, while bio ditches are sloping, which primarily serves to drain water and only secondarily to clean it. In addition, a rain garden should not be confused with a garden pond in which standing water is constantly present; nor with an artificial pond (reservoir) for storing rainwater, which stores rainwater for much longer than the rain garden.

The quantity and quality of green infrastructure is particularly important for mitigating the negative effects of climate change. Especially in the downtown area, the shading ability of vegetation is important, which can reduce the over-warming of public areas during heat wave periods and mitigate the urban heat island effect. However, this requires a healthy, well-closed canopy and multilevel planting. According to a survey conducted by us in downtown of Kecskemét [3], the majority of woody vegetation is not in good health condition. Most trees reach the upper limit of their viability within $10-15$ years.

Considering that changes in the urban area (large-scale built-up areas) allow limited greening in the traditional sense (parks, alleys, gardens, etc.), more attention needs to be paid to other elements of green infrastructure. The use of green roofs and green facades increases green areas without the need for space, contributes to urban air quality, shading and insulating buildings, and its aesthetic role is not negligible. Unfortunately, these elements of green infrastructure are only rarely found not only in Kecskemét but also in Hungary.

\section{Acknowledgment}

Thank you for the support of EFOP-3.6.1-16-2016-00006 „Developing and expanding research potential at John von Neumann University" project. This project is supported by the Hungarian State and the European Union, co-financed by the European Social Fund, under the Széchenyi 2020 program.

\section{References}

[1] Dóka R. (2011): Tájhasználati változások, tájértékek és tájvédelem a Duna-Tisza közén. In: Rakonczai J. (szerk.): Környezeti változások és az Alföld. Nagyalföld Alapítvány kötetei 7. Nagyalföld Alapítvány Békéscsaba, pp. 315-325.

[2] Hoyk E. (2006): A szárazodás hatása a vegetáció alakulására homokhátsági szikes tavak példáján. In: Kiss, A; Mezősi, G; Sümeghy, Z (szerk.) Táj, környezet és társadalom: ünnepi tanulmányok Keveiné Bárány llona professzor 
asszony tiszteletére. Szeged, SZTE Éghajlattani és Tájföldrajzi Tanszék, SZTE Természeti Földrajzi és Geoinformatikai Tanszék, pp. 293-303.

[3] Hoyk E. - Kanalas I. - Farkas J.Zs. - Szemenyei Gy. (2019): Környezeti kihívások a városfejlesztésben Kecskemét példáján. In: Alföldi Kaleidoszkóp. A magyar vidék a XXI. században. Tanulmányok a 70 éves Csatári Bálint köszöntésére. Kecskemét, pp. 133-146.

[4] IPCC (2014). Climate Change 2014 - Synthesis Report. Summary for Policymakers. https://www.ipcc.ch/site/assets/uploads/2018/02/AR5 SYR FINAL SPM.pdf

[5] Iványosi Szabó A. - Hoyk E. (2016): Kecskeméti táj, kecskeméti tájváltozások. Forrás, 48. évf. 7-8. sz., pp. 10-35.

[6] Magyar Közút Nonprofit Zrt.: Az országos közutak keresztmetszeti forgalma 2009-2017

[7] Rakonczai J. - Fehér Zs. (2015): A klímaváltozás szerepe az Alföld talajvízkészleteinek időbeli változásaiban. Hidrológiai Közlöny, 95:(1). pp. 1-15.

[8] http://levegominoseg.hu/automata-merohalozat 